\title{
OPTIMUM PLOT SIZE AND NUMBER OF REPLICATIONS IN PAPAYA FIELD EXPERIMENT ${ }^{1}$
}

\author{
EDILSON ROMAIS SCHMILDT ${ }^{2}$, OMAR SCHMILDT ${ }^{3}$, COSME DAMIÃO CRUZ ${ }^{4}$, \\ LAERCIO FRANCISCO CATTANEO ${ }^{5}$, GERALDO ANTÔNIO FERREGUETTI ${ }^{6}$
}

\begin{abstract}
The aim of this study was to estimate the optimum plot size and number of replications in papaya field experiments. Eleven variables were evaluated in four cultivars of papaya with planting in different seasons between 2011 and 2013 in the north of the Espírito Santo state. Analysis were made from blank test applied to 240 selected for planting season and cultivate plants in commercial fields. The determination of optimum plot size was performed by applying the methodologies of modified maximum curvature and maximum curvature of coefficient of variation. The determination of the number of repetitions was taken from the least significant difference in average $20 \%$ and $30 \%$. The optimum plot size proved the same by the two methods studied for most evaluations. The optimum size required differs among cultivars, between variables and between planting seasons, with the largest number of plants was required for the variables number of fruits per plant and yield per plant. We conclude that the optimal number of papaya plants planted in the field is six plants per plot using three replications.
\end{abstract}

Index terms: Carica papaya L., experimental precision, experimental planning.

\section{TAMANHO ÓTIMO DE PARCELAS E NÚMERO DE REPETIÇÕES EM EXPERIMENTOS DE CAMPO COM MAMOEIRO}

RESUMO- Objetivou-se neste estudo estimar o tamanho ótimo de parcelas e o número de repetições em mamoeiro cultivado a campo. Avaliaram-se onze variáveis em quatro cultivares de mamoeiro com plantio em diferentes estações do ano entre 2011 e 2013 no norte do Espírito Santo. As análises foram feitas a partir de ensaio em branco aplicado em 240 plantas selecionadas, por época de plantio e por cultivar, em lavouras comerciais. A determinação do tamanho ótimo de parcela foi feita aplicando-se as metodologias de máxima curvatura modificado e máxima curvatura do coeficiente de variação. A determinação do número de repetições foi feita a partir da diferença mínima significativa da média de $20 \%$ e $30 \%$. O tamanho ótimo da parcela se mostrou o mesmo pelas duas metodologias estudadas para a maioria das avaliações. O tamanho ótimo requerido difere entre as cultivares, entre as variáveis e entre as épocas de plantio, sendo que o maior número de plantas foi requerido para as variáveis número de frutos por planta e produção por planta. Concluiu-se que o número ótimo de plantas em experimentos de mamoeiro plantados a campo é de seis plantas por parcela com uso de três repetições.

Termos para indexação: Carica papaya L., precisão experimental, planejamento experimental.

\footnotetext{
'(Trabalho 003-15). Recebido em: 05-01-2015. Aceito para publicação em: 30-07-2015.

${ }^{2}$ Eng. Agr., Dr., Professor, Dept ${ }^{\circ}$ de Ciências Agrárias e Biológicas, Universidade Federal do Espírito Santo, CEUNES, São Mateus, ES. E-mail: e.romais.s@gmail.com

${ }^{3}$ Eng. Agr., Dr., Pós Doutorando (PNPD/CAPES), Dept ${ }^{\circ}$ de Ciências Agrárias e Biológicas, Universidade Federal do Espírito Santo, CEUNES, São Mateus, ES. E-mail: omarschmildt@gmail.com

${ }^{4}$ Eng. Agr., Dr., Professor, Dept ${ }^{\circ}$ de Biologia Geral, Universidade Federal de Viçosa, Campus Viçosa, Viçosa, MG. E-mail: cdcruz@ ufv.br

${ }^{5}$ Eng. Agr., Dr., Instituto Capixaba de Pesquisa, Assistência Técnica e Extensão Rural, Linhares, ES. E-mail: 1fcattaneo@hotmail.com ${ }^{6}$ Eng. Agr., Caliman Agrícola S/A, Linhares, ES. E-mail: geraldo@caliman.com.br
} 


\section{INTRODUCTION}

Field experiments with papaya are common and should be established given the high demand of information in the different areas, emphasizing the studies regarding crop science, mechanization, breeding, irrigation and drainage, physiology, entomology, phytopathology, weed control, among other areas.

Regardless the experimental design, the randomization and existence of at least two replications are crucial, in order to estimate the error and, consequently, the analysis of variance can be performed (STEEL et al., 1997). The analysis of variance is a statistical tool that allows determining the experimental error, but local control and caution are ways to avoid that the variation not explained to be minimally influenced by external factors or by measuring errors. Thus, in order to minimize the experimental error, several strategies could be used, being part of good planning. The choice of the experimental design is one of these strategies and will depend, among others, on the studied crop, the number of treatments, the environmental influences on each treatment, and the number of experimental units (FEDERER, 1977).

There are several methods to determine the optimum plot size, where the most used is the modified maximum curvature method, according to Meier and Lessman (1971). Recently, Paranaíba et al. (2009) proposed the maximum curvature of the coefficient of variation method, which has the advantage of reducing the calculation necessary to determine the optimum plot size.

Research to determine the optimum plot size in the field were performed for several crops, such as abacaxi (LEONARDO et al., 2014), passion fruit (STORCK et al., 2014), canola (CARGNELUTTI FILHO et al., 2015), sunflower (SOUZA et al., 2015), among others.

In the literature, we only find the studies of Lima et al. (2007) and Brito et al. (2012), with the aim of determining the optimum plot size with papaya plants. However, in both studies the evaluation concerned the performance of juvenile plants grown in specific greenhouse conditions.

As there are no studies regarding plot optimization for field experiments of papaya, each researcher uses the size that better suits to its reality, determined by the availability of physical, technical, and financial resources. Therefore, in the field studies involving papaya crop it is possible to find varied plot sizes. There are reports studies using only one (PRATISSOLI at al., 2007) up to twenty plants per plot (VIVAS et al., 2011).

Considering that the experimental error is closely related to the size of experimental plots (FEDERER, 1977) and that there is an optimum plot size for each character in each crop, it is concluded that different sampling errors in field experiments of papaya (COCHRAN, 1977) are assumed by researchers within each plot and previously to set the experiments. One of the consequences of this is that a good portion of the experimental variability measured by the variation coefficients of some of these trials could have been reduced if the plots had the minimum size and number.

The aim of the present study was to determine the optimum plot size assuming different number of replications for experiments with different papaya cultivars and planting times.

\section{MATERIAL AND METHODS}

The study was performed at the Santa Teresinha farm of the Caliman Agrícola S.A company, (parallel $19^{\circ} 11^{\prime} 49^{\prime \prime}$ of latitude south and $40^{\circ} 05^{\prime} 52^{\prime \prime}$ of longitude west) and approximate altitude of 30 meters, in the municipality of Linhares, Espírito Santo. The climate of the region is AWi type (humid tropical), with rain in the summer and dry winter (ROLIM et al., 1999).

The varieties of papaya THB and Golden, besides the hybrids $\mathrm{F}_{1}$ Tainung and Uenf/Caliman 01, were studied regarding the determination of plot size and number of replications.

The sowing of the seeds to produce the plants was performed in a nursery with polyolefin net (shading net 50\%). Trays containing 96 cartridges with capacity of $50 \mathrm{~cm}^{3}$ filled with Bioplant ${ }^{\mathbb{R}}$ substrate plus Basacot mini $3 \mathrm{M}^{\circledR}$ in the proportion of $10 \mathrm{~kg}$ $\mathrm{m}^{-3}$ of substrate were used, according to Paixão et al. (2012), in which two seeds by cartridge were sown.

After being acclimatized the plants were transplanted in the field, around 40 days after they were sown, when its height was from 12 to $15 \mathrm{~cm}$.

Three plants per hole were planted in order to assure a greater number of hermaphrodite plants. For the cultivars THB and Golden the spacing was $3.6 \times 1.5 \mathrm{~m}$ and for the hybrids Tainung 01 and Uenf/ Caliman 01, the spacing was $3.6 \mathrm{~m}$ between rows and $2.0 \mathrm{~m}$ between plants, in podzolic red yellow soil of sandy-clay texture. The sexing was done after three months from planting, being kept a hermaphrodite plant per hole

The first evaluations were performed when the first fruits in ripening stage two (2) appeared, around eight months after planting. Fertilization, 
phytosanitary control and other cultural practices were performed according the recommendation for the crop (MARTELLETO et al; 2013; COSTA et al., 2013).

The assessed variables were: plant height $(\mathrm{PH})$ - corresponding to the distance between soil surface, contiguous to plant neck, and the insertion point of the youngest leaf, expressed in centimeters; height of the first fruit insertion (HFFI) - corresponding to the distance between soil surface, contiguous to the plant neck, and the insertion point of the first fruit, in centimeters; trunk diameter (TD) - evaluated at $20 \mathrm{~cm}$ from the soil, using a caliper, expressed in centimeters; number of marketable fruits (NMF) - all the fruits of the plant meeting the commercial standard; fruit mass (FM) - expressed in grams, measured in a precision scale with three decimal places; potential production per tree in the first year (PP), obtained by the multiplication between NMF and FM; fruit length (FL) - measured with caliper and expressed in centimeters; diameter of the median region of the fruit (DF) - expressed in centimeters; thickness of fruit flesh (TF) - measured with caliper and expressed in centimeters; diameter of the fruit cavity (DFC) - measurement taken after a cross cutting of the fruit in the equatorial region, expressed in centimeters; total soluble solids (TSS), by direct reading in bench refractometer, and expressed in ${ }^{\circ}$ Brix and internal firmness of the fruit (FIRM) determined using a penetrometer (Instrutherm, medol PTR-100) and expressed in Newton (N), measured in three equidistant points along the thickness of the flesh from the cross cutting of the fruit in the equatorial region, using a proble of $7.9 \mathrm{~mm}$. For the variables related to fruit, MFR to FIRM, one fruit of each of the 240 plants of each cultivar was evaluated. These fruits were harvested in ripening stage two (2), with up to $25 \%$ of the skin in the yellow color and evaluated in the same day in the postharvest lab of the Caliman company.

The time of planting in the field, as well as the planted area and the data collection time are shown in Table 1. In each area, 240 plants were evaluated, in a blank assay, with four rows of 60 plants located in the center of the field. Altogether 1920 plants were evaluated.

\section{Determination of optimum plot size}

For each of the twelve characters evaluated in the 240 plants of the black essay performed for each of the four cultivars of the different planting times, it was determined the optimum plot size using two methods: Modified Maximum Curvature Method, according to Meier and Lessman (1971), that we have assigned by $\mathrm{X}_{0} \mathrm{ML}$; and the Maximum Curvature of the Coefficient of Variation Method according to Paranaíba et al. (2009) that we have assigned by $\mathrm{X}_{0} \mathrm{P}$.

For the determination of the $\mathrm{X}_{0} \mathrm{ML}, 240$ plants of the blank assay were structured in basic experimental units (BEU), where each BEU was constituted of one plant. The evaluations of the 12 variables in the field were made in each BEU. Then, with the data available and the precise identification of each plant, it was proceeded the calculations. For that, the BEU were grouped using the number of exact divider plants of the total number of plants of the blank assay, varying from one (1) up to $30 \mathrm{BEU}$, forming 11 groupings. For each specific grouping it was assesses all the possibilities of grouping composition by the evaluation of the plants within each of the four rows (DL) of 60 plants or plants between rows (EL). Thus, the grouping size (Xi) were, in BEU: X1 = 1 (1DL x 1EL); X2 = 2 (1DL $x$ $2 \mathrm{EL}, 2 \mathrm{DL} \times 1 \mathrm{EL}) ; \mathrm{X} 3=3$ (3DL $\times 1 \mathrm{EL}) ; \mathrm{X} 4=4$ (4DL $\mathrm{x} 1 \mathrm{EL}, 1 \mathrm{DL} \mathrm{x} 4 \mathrm{EL}$ and $2 \mathrm{DL} \mathrm{x} 2 \mathrm{EL}) ; \mathrm{X} 5=5(5 \mathrm{DL}$ $\mathrm{x} 1 \mathrm{EL}) ; \mathrm{X} 6=6(6 \mathrm{DL} \times 1 \mathrm{EL}$ and $3 \mathrm{DL} \times 2 \mathrm{EL}) ; \mathrm{X} 7=$ 10 (10DL $x 1 \mathrm{EL}$ and 5DL $x$ 2EL); $\mathrm{X} 8=12$ (12DL $\mathrm{x}$ $1 \mathrm{EL}, 6 \mathrm{DL} x$ 2EL and 3DL $x$ 4EL); $\mathrm{X} 9=15$ (15DL $\mathrm{x}$ $1 \mathrm{EL}) ; \mathrm{X} 10=20(20 \mathrm{DL} \times 1 \mathrm{EL}, 10 \mathrm{DL} \times 2 \mathrm{EL}$ and $5 \mathrm{DL}$ $x$ 4EL); X11 = 30 (30DL x 1EL and 15DL x 2EL).

For each of the $\mathrm{X}_{\mathrm{i}} \mathrm{BEU}$ it was calculated the variance among plots $\left(\mathrm{V}_{(\mathrm{xi})}\right)$, the coeficiente of variation among plots $\left(\mathrm{CV}\left({ }_{\mathrm{xi}}\right)\right)$ and the variance by BEU among the plots of $X_{\mathrm{i}} \mathrm{BEU}$ of size, given by $\mathrm{VU}\left(\mathrm{x}_{\mathrm{i}}\right)=\mathrm{V}\left(\mathrm{x}_{\mathrm{i}}\right) / \mathrm{X}_{\mathrm{i}}^{2}$.

From the group of 11 information of the $\mathrm{X}_{\mathrm{i}}$ and $\mathrm{CV}\left({ }_{\mathrm{Xi}}\right)$ the equation $\mathrm{CV}\left({ }_{\mathrm{Xi}}\right)=\beta_{0} \mathrm{X}_{\mathrm{i}}^{-\beta}{ }_{1}$ was adjusted. Using the values of the constant $\left(\beta_{0}\right)$ and of the regression coefficient, $\left(\beta_{1}\right)$ the plot size was calculated through the equation:

$$
X_{0} M L=\left[\frac{\hat{\beta}_{0}^{2} \hat{\beta}^{2}{ }_{1}\left(2 \hat{\beta}_{1}+1\right)}{\hat{\beta}_{1}+2}\right]^{\frac{1}{2+2 \hat{\beta}_{1}}}
$$

To calculate $\mathrm{X}_{0} \mathrm{P}$, the 240 plants of the four rows of the blank assay were numbered from 1 to 240, according the their sequence in the adjacent rows. From these 240 plants it was determined the sample mean $(\mathrm{m})$, sample variance $\left(\mathrm{s}^{2}\right)$, and the estimation of the spatial autocorrelation coefficient of first order $(\hat{\rho})$, using the number sequence of the plants:

$\mathrm{Di}=\mathrm{xi}-\mathrm{x}$ e $\rho=\sum_{\mathrm{i}=2}^{240} \mathrm{DiD}_{\mathrm{i}-1} / \sum_{\mathrm{i}=2}^{240} \mathrm{D}_{\mathrm{i}}^{2}$ and where $\mathrm{x}_{\mathrm{i}}$ is the value observed in the plan $i$.

Therefore, the plot size $\mathrm{X}_{0} \mathrm{P}$ was determined by: $(10 / m)\left(\sqrt[3]{\left.2\left(1-\rho^{2}\right) s^{2} m\right)}\right.$ 
(Determination of plot size assuming different number of replications

In order to determine the necessary plot size assuming different number of replications of each variable for each cultivar for each planting time, it was used the least significant difference between means $\left(\mathrm{D}_{\mathrm{i}}\right)$ through the method proposed by Hatheway (1961). For that, the heterogeneity index (b) was determined, through the logarithm of the function, $\mathrm{VU}_{(\mathrm{Xi})}=\mathrm{V}_{\mathrm{l}} / \mathrm{X}_{\mathrm{i}}^{\mathrm{b}}$ according to Smith (1938).

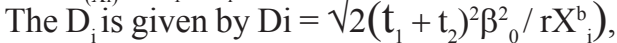
where $r$ is the number of replications, $\beta_{0}, X_{i}$, and $b$ were previously defined, $t_{1}$ is the tabulated value of $t$ for the significance tests (bilateral at $5 \%$ ) and $t_{2}$ is the tabulated value of $t$ corresponding an error of $2(1-p)$, where $p=0,80$ the probability of obtaining significant results. The tabulated values of the $t$ distribution were obtained with gl degrees of freedom of the residue, assuming a completely randomized design, that $\mathrm{gl}=\mathrm{I}(\mathrm{r}-1)$, where $\mathrm{I}$ is the number of treatments admitted in the exact division $\mathrm{I}=240 /\left(\mathrm{rX}_{\mathrm{i}}\right)$, and $\mathrm{r}$ taken as 2,3,4, and 5 replications and the $\mathrm{X}_{\mathrm{i}}$ the size of the BEU as previously set $(1,2,3,4,5,6$, $10,12,15,20$, and 30$)$. Thus, for each $r$ replication the values of $\mathrm{D}_{\mathrm{i}}$ were obtained, that depending on the $\mathrm{X}_{\mathrm{i}}$ the regression $\mathrm{D}_{\mathrm{i}}=\mathrm{AX}_{\mathrm{i}}^{-\mathrm{B}}$ was estimated. From the linearization of this equation and fixing $\mathrm{D}_{\mathrm{i}}$ as 20 or $30 \%$, the values of $X_{i}$ were obtained, which correspond to the number of plants per plot.

The data were analyzed using the computer resources of the interactive software Matlab (MATLAB, 2010), performing the calculations with thirteen decimal places.

\section{RESULTS AND DISCUSSION}

The results of the analysis from the 240 plants of each of the four papaya cultivars in different planting times are shown in Table 2.

Although the means $(\mathrm{m})$ of the characters plant height $(\mathrm{PH})$, height of the first fruit insertion (HFFI), fruit mass (FM), and fruit diameter (FD) were not evaluated by test of means, they were greater for the hybrids Tainung 01 e Uenf/Caliman 01, of the "Formosa" group, when compared to the varieties THB and Golden, of the "solo" group. These results are in agreement with the expected and that were observed by Silva (2013), evaluating the same cultivars, in a germplasm bank, in the autumn planting of 2011.

In the evaluation of the means of the number of marketable fruits (NMF) per plant of THB, it was found NMF $=78$, in the summer of 2012, and NMF $=54$, in the summer of 2013. Despite this difference of 24 fruits per plant, which might represent $12 \mathrm{~kg}$ of fruit per plant, this result is according the reality of commercial planting, since the production of papaya is largely influenced by environmental factors (DAMASCENO JÚNIOR et al., 2008). It is interesting to show that the optimum size is of six plants by plot for NMF of the two planting times, through both methodologies used. This highlights that only the average is not enough to affect the differences in the optimum plot size, through the methodologies of Meier and Lessman (1971) and Paranaíba et al. (2009).

In the comparison of the optimum plot size between the Modified Maximum Curvature Method $\left(\mathrm{X}_{0} \mathrm{ML}\right)$ of Meier and Lessman (1971) and the Maximum Curvature of the Coefficient of Variation Method ( $\left.\mathrm{X}_{0} \mathrm{P}\right)$ of Paranaíba et al. (2009), it was observed that both methods showed similar results in $92 \%$ of the 60 evaluations performed, and that in the other evaluations where the results diverged, the method of Paranaíba et al. (2009) provided an estimate of the optimum plot size with differences of only one plant less. These results of the comparison of both methods disagree of those found by Paranaíba et al. (2009) working with rice. These authors found the greater plot size was observed for maximum curvature of the coefficient of variation method. Thus, the results found in the present study should not be extrapolated to other variables that may be evaluated or even to working plots with different sizes of the study, which was 240 plants.

The optimum plots size showed variation among the variables within the same cultivar, as well as for the same variable among cultivars and also for 'THB' between planting times. So, the optimum plot size varied from two plants by plot through the evaluation of FD and total soluble solids (TSS) in the variety Golden, and flesh firmness (FIRM) in the hybrid Tainung 01, to six plants by plot observed for NMF and production per plant (PP) in most varieties and planting times. Storck et al. (2014), evaluating thirteen variables in eight passion fruit genotypes, in the same planting time, have also found different plot size requirements among the variables and genotypes. They also observed the greater sampling size was required to number of fruits per plant and production per plant. Similar response was observed by Lima et al. (2007), evaluating five variables in the 'Golden' and 'Tainung 01' papaya grown in polyethylene bags, in greenhouse.

Besides the optimum plot size, it is important that the researcher situate himself around the number of replications. In Table 2 , it is seen that $42 \%$ of the evaluations assume lest significant difference 
of the means of $20 \%\left(D_{i}=20 \%\right)$, using only two replications. The percentage rises to $83 \%$ using three replications and reaches $97 \%$ using five replications. The variable production per tree (PP) requires the larger plot size, where this size is of size plants for the four varieties. For 'THB' and 'Uenf/Caliman 01' in the summer planting of 2012, the adoption of six plans by plot and precision $D_{i}=20 \%$, requires an experiment with more than 5 replications. Therefore, considering the researcher is interested in the evaluation of all variables evaluated in the present study, he can use the optimum size of six plants by plot, in three replications (18 plants by treatment in the experiment), assuming $\mathrm{D}_{\mathrm{i}}=30 \%$. In order to keep the maximum $\mathrm{D}_{\mathrm{i}}$ of $20 \%$, the researcher could use 11 plants by plot and two replications (22 plants by treatment in the experiment), seven plants by plot and five replications ( 35 plants by treatment in the experiment) or other options as shown in Table 2. Similar results of organization among the number of plants by plot and the number of replications were also shown by Souza et al. (2015), which determined the optimum plot size for sunflower.

Still regarding plot size, it is seen in Table 2 that the researcher might use a plot size smaller than the optimum. However, in this case he will have to choose a higher number of replications and sometime assume a greater percentage for $\mathrm{D}_{\mathrm{i}}$. In the other hand, the researcher that is using more than six plants by plot with three replications or more will be decreasing $D_{i}$, despite spending more than needed in its experimentation.

The results of the present study are useful to guide researchers in papaya field experiments, since there is not a standard number of plants by plot and number of replications, as can be observed in the following studies: five plants by plot (OLIVEIRA et al., 2014), six plants by plot (REIS et al., 2015), eight plants by plot (DIAS et al., 2011), ten plants by plot (CARDOSO et al., 2014), twelve plants by plot (FERREIRA et al., 2012), and fifteen plants by plot (MESQUITA et al., 2007).

The optimum sampling size of six plants by plot should be understood as the number of plants to be evaluated, around eight months after planting. This does not mean the researcher should use only six plants by plot. This concern should take into account the training particularities of papaya fields, among which we could cite: The interest variables fall upon hermaphrodite plants and depending on segregation, not all plants in a plot are hermaphrodite; need to eliminate diseased plants manly those with viral diseases. Thus, the researcher, as far as possible, should establish each plot with number of plants greater than six. The additional number of plants relative to what was set in this study will depend, among other factor, on the financial resources and experimental area available.

TABLE 1 - Planting time, planted are and, data sampling time of different papaya cultivars, in the Espírito Santo state, for determination of plot size and number of replications.

\begin{tabular}{cccc}
\hline Planting time & Cultivar & Planted area (ha) & Data sampling time \\
\hline $16 / 02 / 2012$ (verão) & THB & 6,0 & $09 / 10 / 2012^{(1)}$ \\
$16 / 02 / 2012$ (verão) & Tainung 01 & 6,0 & $15 / 10 / 2012^{(1)}$ \\
$16 / 02 / 2012$ (verão) & Uenf/Caliman 01 & 6,0 & $05 / 10 / 2012^{(1)}$ \\
$10 / 04 / 2012$ (outono) & Golden & 7,5 & $03 / 12 / 2012^{(1)}$ \\
$16 / 07 / 2012$ (inverno) & THB & 18,0 & $19 / 03 / 2013$ \\
$31 / 10 / 2012$ (primavera) & THB & 20,5 & $05 / 06 / 2013$ \\
$15 / 01 / 2013$ (verão) & THB & 12,0 & $13 / 09 / 2013$ \\
$03 / 06 / 2013$ (outono) & THB & 12,0 & $29 / 01 / 2014$ \\
\hline
\end{tabular}

(1) The evaluations performed in the fruit lasted over 10 days. 
TABLE 2 - Mean (m), optimum plot size determined through the Modified Maximum Curvature Method $\left(\mathrm{X}_{0} \mathrm{ML}\right)$ according to Meier and Lessman (1971) and through the Maximum Curvature of the Coefficient of Variation Method $\left(\mathrm{X}_{0} \mathrm{P}\right)$ according to Paranaíba et al. (2009), the plot size according to the number of replications for a least significant difference of the mean (D) of $20 \%$ and $30 \%$, evaluated in variables of papaya in different cultivars and planting times.

\begin{tabular}{|c|c|c|c|c|c|c|c|c|c|c|c|}
\hline \multirow{3}{*}{ Variables ${ }^{(1)}$} & \multirow{3}{*}{$\mathrm{m}$} & \multirow{3}{*}{$\mathrm{X}_{0} \mathrm{ML}$} & \multirow{3}{*}{$\mathrm{X}_{0} \mathrm{P}$} & \multicolumn{4}{|c|}{$\mathrm{D}=20 \%$} & \multicolumn{4}{|c|}{$\mathrm{D}=30 \%$} \\
\hline & & & & \multicolumn{4}{|c|}{ Replications } & \multicolumn{4}{|c|}{ Replications } \\
\hline & & & & 2 & 3 & 4 & 5 & 2 & 3 & 4 & 5 \\
\hline & \multicolumn{11}{|c|}{ THB - planting in the summer of 2012} \\
\hline $\mathrm{PH}$ & 169.75 & 3 & 3 & 3 & 3 & 2 & 2 & 2 & 2 & 2 & 2 \\
\hline HFFI & 78.05 & 4 & 4 & 6 & 5 & 4 & 4 & 4 & 3 & 3 & 3 \\
\hline $\mathrm{TD}$ & 10.51 & 4 & 4 & 4 & 3 & 3 & 3 & 3 & 2 & 2 & 2 \\
\hline NMF & 77.61 & 6 & 6 & 9 & 7 & 6 & 6 & 6 & 5 & 4 & 4 \\
\hline $\mathrm{FM}$ & 545.67 & 4 & 4 & 6 & 5 & 4 & 4 & 4 & 3 & 3 & 3 \\
\hline PP & 42.31 & 6 & 6 & 11 & 9 & 8 & 7 & 7 & 6 & 5 & 5 \\
\hline FL & 14.52 & 3 & 3 & 3 & 2 & 2 & 2 & 2 & 2 & 2 & 1 \\
\hline FD & 8.63 & 3 & 2 & 3 & 2 & 2 & 2 & 2 & 2 & 1 & 1 \\
\hline $\mathrm{TF}$ & 2.61 & 4 & 4 & 4 & 3 & 3 & 3 & 3 & 2 & 2 & 2 \\
\hline DFC & 4.71 & 4 & 4 & 4 & 4 & 3 & 3 & 3 & 3 & 2 & 2 \\
\hline TSS & 11.23 & 3 & 3 & 3 & 3 & 2 & 2 & 2 & 2 & 2 & 2 \\
\hline \multirow{2}{*}{ FIRM } & 118.81 & 4 & 3 & 4 & 4 & 3 & 3 & 3 & 3 & 2 & 2 \\
\hline & \multicolumn{11}{|c|}{ Tainung 01 - planting in the summer of 2012} \\
\hline $\mathrm{PH}$ & 233.18 & 3 & 3 & 3 & 2 & 2 & 2 & 2 & 2 & 2 & 1 \\
\hline HFFI & 118.29 & 3 & 3 & 4 & 3 & 3 & 3 & 3 & 2 & 2 & 2 \\
\hline TD & 11.54 & 3 & 3 & 3 & 3 & 2 & 2 & 2 & 2 & 2 & 2 \\
\hline NMF & 28.50 & 5 & 5 & 8 & 6 & 5 & 5 & 5 & 4 & 4 & 3 \\
\hline FM & 1381.20 & 4 & 4 & 5 & 4 & 4 & 3 & 4 & 3 & 3 & 2 \\
\hline $\mathrm{PP}$ & 39.32 & 6 & 6 & 9 & 7 & 6 & 6 & 6 & 5 & 4 & 4 \\
\hline FL & 24.40 & 3 & 3 & 3 & 2 & 2 & 2 & 2 & 2 & 1 & 1 \\
\hline FD & 10.77 & 3 & 3 & 3 & 2 & 2 & 2 & 2 & 2 & 2 & 1 \\
\hline $\mathrm{TF}$ & 3.34 & 3 & 3 & 3 & 3 & 3 & 2 & 2 & 2 & 2 & 2 \\
\hline DFC & 6.07 & 3 & 3 & 4 & 3 & 3 & 3 & 3 & 2 & 2 & 2 \\
\hline TSS & 11.05 & 4 & 4 & 5 & 4 & 4 & 3 & 4 & 3 & 3 & 2 \\
\hline FIRM & 125.59 & 2 & 2 & 2 & 2 & 1 & 1 & 1 & 1 & 1 & 1 \\
\hline
\end{tabular}

Uenf/ Caliman 01 - planting in the summer of 2012

$\begin{array}{ccccccccccccc}\text { PH } & 216.90 & 3 & 3 & 3 & 2 & 2 & 2 & 2 & 2 & 2 & 1 \\ \text { HFFI } & 87.78 & 5 & 4 & 6 & 5 & 5 & 4 & 4 & 4 & 3 & 3 \\ \text { TD } & 12.07 & 4 & 3 & 4 & 3 & 3 & 3 & 3 & 2 & 2 & 2 \\ \text { NMF } & 38.30 & 6 & 6 & 10 & 8 & 7 & 6 & 7 & 6 & 5 & 4 \\ \text { FM } & 1116.30 & 4 & 4 & 5 & 4 & 3 & 3 & 3 & 3 & 2 & 2 \\ \text { PP } & 42.89 & 6 & 6 & 11 & 9 & 8 & 7 & 8 & 6 & 5 & 5 \\ \text { FL } & 21.52 & 3 & 3 & 3 & 2 & 2 & 2 & 2 & 2 & 2 & 1 \\ \text { FD } & 10.17 & 3 & 3 & 3 & 2 & 2 & 2 & 2 & 2 & 1 & 1 \\ \text { TF } & 2.71 & 3 & 3 & 4 & 3 & 3 & 3 & 3 & 2 & 2 & 2 \\ \text { DFC } & 5.69 & 3 & 3 & 4 & 3 & 3 & 2 & 3 & 2 & 2 & 2 \\ \text { TSS } & 13.12 & 3 & 3 & 3 & 3 & 2 & 2 & 2 & 2 & 2 & 2 \\ \text { FIRM } & 124.60 & 4 & 4 & 4 & 3 & 3 & 3 & 3 & 2 & 2 & 2\end{array}$

$\begin{array}{cccccccccccc}\text { PH } & 206.26 & 3 & 3 & 3 & 2 & 2 & 2 & 2 & 2 & 1 & 1 \\ \text { HFFI } & 97.79 & 3 & 3 & 3 & 3 & 2 & 2 & 2 & 2 & 2 & 2 \\ \text { TD } & 10.73 & 3 & 3 & 3 & 2 & 2 & 2 & 2 & 2 & 2 & 1\end{array}$




\begin{tabular}{|c|c|c|c|c|c|c|c|c|c|c|c|}
\hline \multirow{3}{*}{ Variables ${ }^{(1)}$} & \multirow{3}{*}{ M } & \multirow{3}{*}{$\mathrm{X}_{0} \mathrm{ML}$} & \multirow{3}{*}{$\mathrm{X}_{0} \mathrm{P}$} & \multicolumn{4}{|c|}{$\mathrm{D}=20 \%$} & \multicolumn{4}{|c|}{$\mathrm{D}=30 \%$} \\
\hline & & & & \multicolumn{4}{|c|}{ Repetições } & \multicolumn{4}{|c|}{ Repetições } \\
\hline & & & & 2 & 3 & 4 & 5 & 2 & 3 & 4 & 5 \\
\hline NMF & 51.07 & 5 & 5 & 7 & 6 & 5 & 4 & 5 & 4 & 3 & 3 \\
\hline FM & 524.47 & 4 & 4 & 5 & 4 & 4 & 3 & 4 & 3 & 3 & 2 \\
\hline PP & 26.77 & 6 & 5 & 8 & 7 & 6 & 5 & 6 & 5 & 4 & 4 \\
\hline FL & 13.24 & 3 & 3 & 3 & 2 & 2 & 2 & 2 & 2 & 1 & 1 \\
\hline FD & 8.73 & 2 & 2 & 2 & 2 & 2 & 2 & 2 & 1 & 1 & 1 \\
\hline $\mathrm{TF}$ & 2.70 & 3 & 3 & 3 & 3 & 2 & 2 & 2 & 2 & 2 & 2 \\
\hline DFC & 5.35 & 3 & 3 & 4 & 3 & 3 & 2 & 3 & 2 & 2 & 2 \\
\hline TSS & 12.32 & 2 & 2 & 2 & 2 & 2 & 2 & 2 & 1 & 1 & 1 \\
\hline \multirow[t]{2}{*}{ FIRM } & 99.64 & 3 & 3 & 3 & 2 & 2 & 2 & 3 & 2 & 2 & 2 \\
\hline & \multicolumn{11}{|c|}{ THB - planting in the winter of 2012} \\
\hline $\mathrm{PH}$ & 165.28 & 3 & 3 & 3 & 3 & 2 & 2 & 2 & 2 & 2 & 2 \\
\hline HFFI & 60.39 & 3 & 3 & 4 & 3 & 3 & 2 & 3 & 2 & 2 & 2 \\
\hline TD & 11.27 & 3 & 3 & 3 & 3 & 2 & 2 & 2 & 2 & 2 & 2 \\
\hline \multirow[t]{2}{*}{ NMF } & 74.58 & 5 & 5 & 6 & 5 & 5 & 4 & 4 & 4 & 3 & 3 \\
\hline & \multicolumn{11}{|c|}{ THB - planting in the spring of 2012} \\
\hline PH & 171.92 & 3 & 3 & 4 & 3 & 3 & 2 & 3 & 2 & 2 & 2 \\
\hline HFFI & 86.01 & 4 & 4 & 5 & 4 & 4 & 3 & 4 & 3 & 3 & 2 \\
\hline TD & 10.41 & 3 & 3 & 4 & 3 & 3 & 2 & 3 & 2 & 2 & 2 \\
\hline \multirow[t]{2}{*}{ NMF } & 63.51 & 5 & 5 & 7 & 5 & 5 & 4 & 5 & 4 & 3 & 3 \\
\hline & \multicolumn{11}{|c|}{ THB - planting in the summer of 2013} \\
\hline $\mathrm{PH}$ & 181.05 & 3 & 3 & 4 & 3 & 3 & 2 & 3 & 2 & 2 & 2 \\
\hline HFFI & 77.95 & 4 & 4 & 5 & 4 & 4 & 3 & 4 & 3 & 3 & 2 \\
\hline TD & 10.50 & 3 & 3 & 4 & 3 & 3 & 3 & 3 & 2 & 2 & 2 \\
\hline \multirow[t]{2}{*}{ NMF } & 54.07 & 6 & 6 & 9 & 7 & 6 & 5 & 6 & 5 & 4 & 4 \\
\hline & \multicolumn{11}{|c|}{ THB - planting in the autumn of 2013} \\
\hline $\mathrm{PH}$ & 155.25 & 3 & 3 & 4 & 3 & 3 & 2 & 3 & 2 & 2 & 2 \\
\hline HFFI & 57.90 & 4 & 4 & 5 & 4 & 3 & 3 & 3 & 3 & 2 & 2 \\
\hline TD & 10.01 & 4 & 3 & 4 & 3 & 3 & 3 & 3 & 2 & 2 & 2 \\
\hline NMF & 67.52 & 6 & 5 & 9 & 7 & 6 & 5 & 6 & 5 & 4 & 4 \\
\hline
\end{tabular}

(1) PH: plant height, in m; HFFI: height of first fruit insertion, in m; TD: trunk diameter, in cm; NMF: number of marketable fruits per plant; FM: fruit mass, in g; PP: estimated production per tree in the first year; FL: fruit length, in cm; FD: fruit diameter, in cm; TF: thickness of the flesh, in cm; DFC: diameter of the internal fruit cavity, in cm; TSS: total soluble solids, in degree Brix; FIRM: flesh firmness, in Newtons.

\section{CONCLUSION}

The optimum size for field papaya experiments if six plants by plot, using three replications.

\section{ACKNOWLEDGMENTS}

The authors thank the Caliman Agrícola S.A. by technical support in the field study and the Bioinformatics Laboratory of the Federal University of Viçosa for the conditions to analyze the results. 


\section{REFERENCES}

BRITO, M.C.M.; FARIA, G.A.; MORAIS, A.R.; SOUZA, E.M.; DANTAS, J.L.L. Estimação do tamanho ótimo de parcela via regressão antitônica. Revista Brasileira de Biometria, São Paulo, v.30, n.3, p.353-366, 2012. Disponível em: $\leq$ http:// jaguar.fcav.unesp.br/RME/fasciculos/v30/v30 n3/ A4_Marcio.pdf $>$.

CARDOSO, D.L.; LUZ, L.N.; MACÊDO, C.M.P.; GONÇALVES, L.S.A.; PEREIRA, M.G. Heterosis in papaya: inter and intragroup analysis. Revista Brasileira de Fruticultura, Jaboticabal, v.36, n.3, p.619-619, 2014. Disponível em: $<$ http://www.scielo. br/pdf/rbf/v36n3/v36n3a12.pdf $>$.

CARGNELUTTI FILHO, A.; ALVES, B.M.; BURIN, C.; KLEINPAUL, J.A.; SILVEIRA, D.L. Tamanho de parcela e número de repetições em canola. Bragantia, Campinas, v.74, n.2, p.176-183, 2015. Disponível em: <http://www.scielo.br/pdf/ brag/v74n2/0006-8705-brag-167844990420.pdf $>$.

COCHRAN, W.G. Sampling techniques. $3^{\text {rd }}$ ed. New York: John Wiley \& Sons, 1977. 448p.

COSTA, A.N.; COSTA, A.F.S.; FERREGUETTI, G.A. Cultivo do mamoeiro: manejo da fertilidade do solo e da nutrição do mamoeiro. Informe Agropecuário, Belo Horizonte, v.34, n.275, p.3847, 2013

DAMASCENO JUNIOR, P.C.; PEREIRA, T.N.S.; SILVA, F.F.; VIANA, A.P.; PEREIRA, M.G. Comportamento floral de híbridos de mamoeiro (Carica papaya L.) avaliados no verão e na primavera. Revista Ceres, Viçosa, MG, v.55, n.4, p.310-316, 2008. Disponível em: $<$ http://www.ceres. ufv.br/ceres/revistas/V55N004P04908.pdf>.

DIAS, N.L.P.; OLIVEIRA, E.J.; DANTAS, J.L.L. Avaliação de genótipos de mamoeiro com uso de descritores agronômicos e estimação de parâmetros genéticos. Pesquisa Agropecuária Brasileira, Brasília, v.46, n.11, p.1471-1479, 2011. Disponível em: <http://www.scielo.br/pdf/pab/v46n11/ v46n11a08.pdf $>$.
FEDERER, W.T. Experimental design: theory and application. $3^{\text {rd }}$ ed. New York: Oxford \& IBH Publishing, 1977. 593p.

FERREIRA, J.P; SCHMILDT, O.; SCHMILDT, E.R.; PIANTAVINHA, W.C.; CATTANEO, L.F. Correlações entre características morfo-agronômicas de acessos de mamoeiro. Enciclopédia Biosfera, Goiânia, v.8, n.14, p.246-257, 2012. Disponível em: <http://www.conhecer.org.br/enciclop/2012a/ agrarias/correlacoes.pdf $>$.

HATHEWAY, W. H. Convenient plot size. Agronomy Journal, Madison, v.53, n.4, p.279-280, 1961. Disponível em: <http://www.worldcat.org/title/ convenient-plot-size/oclc/708673253>.

LEONARDO, F. de A.P.; PEREIRA, W.E.; SILVA, S. de M.; ARAÚJO, R. da C.; MENDONÇA, R.M.N. Tamanho ótimo da parcela experimental de abacaxizeiro 'Vitória'. Revista Brasileira de Fruticultura, Jaboticabal, v.36, n.4, p.909-916, 2014. Disponível em: $<$ http://www.scielo.br/pdf/rbf/ v36n4/a18v36n4.pdf $>$.

LIMA, J.F.; PEIXOTO, C.P.; LEDO, C.A.S.; FARIA, G.A. Tamanho ótimo de parcela para experimentos com plantas de mamoeiro em casa de vegetação. Ciência e Agrotecnologia, Lavras, v.31, n.5, p.1411 1415, 2007. Disponível em: <http://www.scielo.br/ pdf/cagro/v31n5/21.pdf $>$.

MARTELLETO, L.A.P.; SUDO-MARTELLETO, M.; MACHADO, A.F.L.; VASCONCELLOS, M.A.S. Cultivo do mamoeiro: manejo fitotécnico. Informe Agropecuário, Belo Horizonte, v.34, n.275, p.29-37, 2013.

MATLAB version 7.10.0 (R2010a). Massachusetts: The MathWorks, 2010.

MEIER, V.D.; LESSMAN, K.J. Estimation of optimum Field plot shape and size for testing yield in Crambe abyssinica Hochst. Crop Science, Madison, v.11, n.5, p.648-650, 1971. Disponível em: $<$ https://dl.sciencesocieties.org/publications/cs/ abstracts $/ 11 / 5 / \mathrm{CS} 0110050648$ ?access $=0 \& v i e w=p d f$ 
MESQUITA, E.F.; CAVALCANTE, L.F.; GONDIM, S.C.; CAVALCANTE, I.H.L.; ARAÚJO, F.A.R.; CAVALCANTE, M.Z. Produtividade e qualidade de frutos do mamoeiro em função de tipos e doses de biofertilizantes. Semina: Ciências Agrárias, Londrina, v.28, n.4, p. 589-596, 2007. Disponível em: <http://www.uel.br/revistas/uel/index.php/ semagrarias/article/view/2890/2448>.

OLIVEIRA, E.J.; FRAIFE FILHO, G.A.; FREITAS, J.P.X.; DANTAS, J.L.L. Desempenho produtivo e interação genótipo $\mathrm{x}$ ambiente em híbridos e linhagens de mamoeiro. Bioscience Journal, Uberlândia, v. 30, n. 2, p. 402-410, 2014. Disponível em: $<\underline{\text { http://www. }}$ seer.ufu.br/index.php/biosciencejournal/article/ view/17988/13755 $>$.

PAIXÃO, M.V.S.; SCHMILDT, E.R.; MATTIELLO, H.N.; FERREGUETTI, G.A.; ALEXANDRE, R.S. Frações orgânicas e mineral da produção de mudas de mamoeiro. Revista Brasileira de Fruticultura, Jaboticabal, v. 34, n.4, p.1105-1112, 2012. Disponível em: $<$ http://www.scielo.br/pdf/rbf/v34n4/18.pdf $>$.

PARANAÍBA, P.F.; FERREIRA, D.F.; MORAIS, A.R. Tamanho ótimo de parcelas experimentais: Proposição de métodos de estimação. Revista Brasileira de Biometria, São Paulo, v.27, n.2, p.255268, 2009. Disponível em: $<$ http://jaguar.fcav.unesp. br/RME/fasciculos/v27/v27 n2/Patricia.pdf $>$. .

PRATISSOLI, D.; ALMEIDA, G.D.; JESUS JÚNIOR, W.C.; VICENTINI, V.B.; HOLTZ, A.M.; COCHETO, J.G. Fertilizante organomineral e argila silicatada como indutores de resistência à varíola do mamoeiro, Idesia, Chile, v.25, n.2, p.63-67, 2007. Disponível em: < http://www.scielo.cl/pdf/idesia/ v25n2/art08.pdf $>$.

REIS, R.C.; SOUZA VIANA, E.S.; JESUS, J.L.; DANTAS, J.L.L.; LUCENA, R.S. Caracterização físico-química de frutos de novos híbridos e linhagens de mamoeiro. Pesquisa Agropecuária Brasileira, Brasília, v.50, n.3, p.210-217, 2015. Disponível em: <http://www.scielo.br/pdf/pab/ v50n3/0100-204X-pab-50-03-00210.pdf $>$.

ROLIM, S.G.; COUTO, H.T.Z.; JESUS, R.M. Mortalidade e recrutamento de árvores na Floresta Atlântica de Linhares (ES). Scientia Forestalis, Piracicaba, n.55, p.49-69, 1999. Disponível em: $<$ http://www.ipef.br/publicacoes/scientia/nr55/cap4. pdf $>$.
SILVA, C.A. Divergência genética entre acessos de mamoeiro e correlações entre suas características no Norte do Espírito Santo. 2013. 66f. Dissertação (Mestrado em Agricultura Tropical) - Universidade Federal do Espírito Santo, Vitória, 2013.

SMITH, H. F. An empirical law describing heterogeneity in the yields of agricultural crops. Journal of Agricultural Science, Cambridge, v.28, n.1, p.1-23, 1938. Disponível em: < $\underline{\text { http://journals. }}$ cambridge.org/action/displayAbstract? fromPage $=0$ $\underline{\text { nline } \& \text { aid }=4689276 \& \text { fileId }=S 0021859600050516}>$.

SOUSA, R.P. de; SILVA, P.S.L.; ASSIS, J.P. de; SILVA, P.I.B.; SILVA, J.C.V. Optimum plot size for experiments with the sunflower. Revista Ciência Agronômica, Fortaleza, v.46, n.1, p.170-175, 2015. Disponível em: < $\underline{\text { http://www.scielo.br/pdf/rca/ }}$ v46n1/0045-6888-rca-46-01-0170.pdf $>$.

STEEL, R.G.D.; TORRIE, J.H.; DICKEY, D.A. Principles and procedures of statistics: a biometrical approach. $3^{\text {rd }}$ ed. New York: MacGrawHill Book Companies, 1997. 666p. STORCK, L.; LÚCIO, A.D.; KRAUSE, W.; ARAÚJO, D.V.; SILVA, C.A. Scaling the number of plants per plot and number of plots per genotype of yellow passion fruit plants. Acta Scientiarum.Agronomy, Maringá, v.36, n.1, p.73-78, 2014. Disponível em: <http:// periodicos.uem.br/ojs/index.php/ActaSciAgron/ article/view/17697/pdf_1>.

VIVAS, M.; SILVEIRA, S.F.; TERRA, C.E.P.; PEREIRA, M.G. Testers for combining ability and selection of papaya hybrids resistant to fungal diseases. Crop Breeding and Applied Biotechnology, Viçosa, MG,v.11, p.36-42, 2011. Disponível em: < http://www.scielo.br/pdf/cbab/ v11n1/v11n1a05>. 